Anne V. McGuire · Samuel B. Mukasa

\title{
Magmatic modification of the uppermost mantle beneath the Basin and Range to Colorado Plateau Transition Zone; Evidence from xenoliths, Wikieup, Arizona
}

\begin{abstract}
Upper mantle xenoliths from Wikieup, AZ, provide abundant evidence for magmatic modification of the uppermost mantle beneath the Transition Zone between the Colorado Plateau and the southern Basin and Range province. Upper mantle lithologies in this xenolith suite are represented by spinel peridotite, wehrlite, plagioclase peridotite, and Al-augite group pyroxenites. Isotopic data for these xenoliths yield relatively uniform values and suggest a common petrogenesis. Alaugite-bearing gabbro and pyroxenite xenoliths from this locality are interpreted to have formed by crystal fractionation processes from parent alkali basalts similar to the Wikieup host basalt. Mineral and whole rock compositions show consistent trends of increasing incompatible element contents $(\mathrm{Fe}, \mathrm{Al}, \mathrm{Ca}, \mathrm{Na}, \mathrm{K}, \mathrm{LIL}$, and LREE), and decreasing compatible element contents $(\mathrm{Mg}, \mathrm{Cr}, \mathrm{Ni})$ from spinel peridotite to wehrlite to plagioclase peridotite to the host basalt composition. These compositional trends are interpreted as resulting from varying degrees of magma-mantle wall rock interaction as ascending mafic magmas infiltrated upper mantle peridotite. Small degrees of melt infiltration resulted in slightly modified spinel peridotite compositions while moderate degrees metasomatized spinel peridotite to wehrlite, and the highest degrees metasomatized it to plagioclase peridotite. Whole rock compositions and clinopyroxene, plagioclase, and whole rock isotopic data suggest that the infiltrating magmas were the same as those from which the gabbros and pyroxenites crystallized, and that they were alkalic in composition, similar to the Wikieup host alkali olivine basalts. Relatively
\end{abstract}

\section{A.V. McGuire}

Dept. of Geosciences, University of Houston,

Houston, TX 77004-5503, U.S.A.

e-mail: amcguire@uh.edu

S.B. Mukasa

Dept. of Geological Sciences, University of Michigan, Ann Arbor, MI 48109, U.S.A.

Editorial responsibility: K. Hodges uniform ${ }^{143} \mathrm{Nd} /{ }^{144} \mathrm{Nd}$ for the mineral separates and whole rocks in spite of the significantly wide range in their ${ }^{147} \mathrm{Sm} /{ }^{144} \mathrm{Nd}(0.71-0.23$ in clinopyroxene) suggests that the Wikieup xenoliths including gabbro, pyroxenite, peridotite, wehrlite, and plagioclase peridotite, are all relatively young rocks formed or metasomatized by a relatively recent magmatic episode.

\section{Introduction}

Geophysical data for the southern Basin and Range Province and the Transition Zone to the Colorado Plateau show high elevations, high geothermal gradient, and abnormal seismic velocities in the uppermost lithospheric mantle (Humphreys and Deuker 1994a,b; Sass et al. 1994), all of which may be indicators of magmatic modification of the upper mantle. Studies of actual mantle samples from beneath the Basin and Range and the Transition Zone indicate a complex variety of rock types (e.g., Frey and Prinz 1978; Menzies et al. 1985; Roden and Shimizu 1993; Wilshire et al. 1988, 1991). The effects of magmatic activity and magmatic underplating on the Basin and Range lower crust and the crust-mantle boundary have been discussed by several authors (McGuire 1994; Wilshire 1990; Wilshire et al. 1988, 1991); however, few studies have documented the effects of magmatic activity on the uppermost mantle beneath the Transition Zone.

Abundant xenoliths of upper mantle and lower crustal material are found in basaltic vents near Wikieup, Arizona, in the Transition Zone between the Colorado Plateau and the southern Basin and Range Province. Studies of gabbroic xenoliths from this locality provide evidence for a thin, $<2-\mathrm{km}$ thick, crust-mantle transition zone formed by underplating of mafic magmas (McGuire 1994). The present study examines the elemental and isotopic characteristics of the upper mantle xenolith suite from Wikieup, which includes abundant composite xenoliths, and numerous mafic and ultramafic xenoliths bearing evidence of magmatic 
modification of the upper mantle beneath Wikieup associated with magmatic underplating of the crust.

\section{Description}

The xenoliths were erupted in two basaltic vents, designated WK1 and WK2, located about $5 \mathrm{~km}$ apart, west of the town of Wikieup, Arizona (Fig. 1). The vents were erupted through fanglomerates on the eastern flanks of the Hualuapai Mountains, in the Transition Zone between the Colorado Plateau and the southern Basin and Range Province. The host basalts are alkali olivine basalts and have been dated, by K-Ar, at 5.3 Ma (Wilshire 1990). Wikieup xenoliths range in size from several centimeters diameter to about $20 \mathrm{~cm}$ diameter; those used in the present study measured at least $2-3 \mathrm{~cm}$ in their minimum dimension and up to $10 \mathrm{~cm}$ in their maximum dimension. Xenolith lithologies collected at Wikieup include gabbronorite, olivine gabbro, Al-augite group and $\mathrm{Cr}$-diopside group pyroxenites, Cr-diopside group spinel peridotites, plagioclase peridotite, wehrlite, and megacrysts of anorthoclase, olivine, spinel, $\mathrm{Al}$-augite, and $\mathrm{Cr}$-diopside. Large numbers of xenoliths at Wikieup are composites of peridotite or wehrlite wallrock and gabbro or pyroxenite veins. Composite xenoliths of gabbro veins in gabbro or pyroxenite wall rock are also found. Although the Wikieup locality is underlain by Proterozoic-aged middle and lower crust (Anderson 1989), Proterozoic crustal rocks are notably absent from the xenolith suite with the possible exception of a small charnockite xenolith (WK1-48) which is included in the present study for comparison.

Wikieup Cr-diopside group spinel peridotite xenoliths contain olivine, green clinopyroxene, brown orthopyroxene, and spinel. Spinel is black in hand sample and red-brown in thin section. Modal mineral contents vary and samples range from lherzolite to harzburgite and dunite; dunite is common. All are medium-grained with allotriomorphic-granular texture.

A large number of wehrlite xenoliths have been collected from Wikieup, and are distinguished from the spinel peridotites described above by their black spinel and pyroxenes. The wehrlites consist primarily of $40-70 \%$ modal olivine, and $30-60 \%$ modal aluminous clinopyroxene. Spinel is black both in hand sample and in thin section, and varies from a few modal percent to as much as $20 \%$ in one sample. Orthopyroxene is usually entirely absent, and when present is no more than $5 \%$ of the mode. The wehrlites are medium-grained, with allotriomorphic-granular texture.

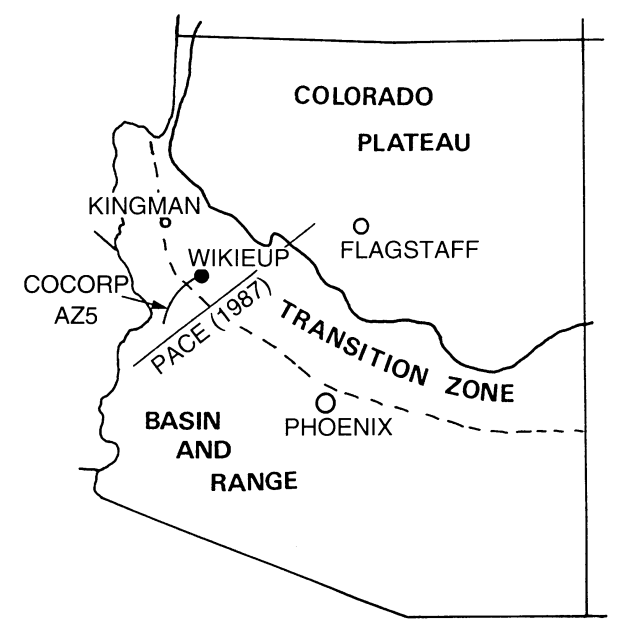

Fig. 1 Map of Arizona showing the location of Wikieup and nearby geophysical profiles, Consortium for Continental Reflection Profiling Arizona 5 (COCORP AZ5) and the Pacific to Arizona Crustal Experiment (PACE)
Wikieup plagioclase peridotite xenoliths have highly variable modes: olivine varies from 15 to $70 \%$, aluminous clinopyroxene from 15 to $60 \%$, plagioclase from 2 to $30 \%$; orthopyroxene is rare and never more than $5 \%$. All samples contain a few percent spinel, and trace amounts of phlogopite and kaersutite are observed in some samples. Many of these samples are technically classified as "gabbronorite" or "olivine gabbbro" due to their high plagioclase and low olivine content; however, they exhibit compositional and textural features that distinguish them from the gabbroic xenoliths at Wikieup, and were initially identified as plagioclase peridotite in the field. These samples will be referred to as "plagioclase peridotite" in this paper to distinguish them from the gabbroic xenoliths.

The plagioclase peridotite xenoliths are medium-grained, and most exhibit allotriomorphic-granular texture. Several are foliated, ranging from slight foliation to xenoliths with obvious banding of olivine-rich, pyroxene-rich, and plagioclase-rich layers and lenses. The foliation and mineral banding is quite distinct from the uniform appearance of the gabbro xenoliths. Clinopyroxene is black in hand sample, and brown in thin section; spinel is black in both hand sample and thin section. Plagioclase is commonly optically zoned, and often exhibits overgrowth rims surrounding euhedral or subhedral cores. Plagioclase grains tend to occur clumped together in lenses or "stringers," and are rarely observed in grain-to-grain contact with spinel or olivine. Plagioclase-olivine contacts exhibit reaction rims of orthopyroxene separating the plagioclase and olivine, and olivines are rounded and resorbed at these contacts; this texture is not observed in the gabbro samples.

Al-augite group pyroxenites are dominated by clinopyroxenites with modes of $95-99 \%$ aluminous clinopyroxene, up to $5 \%$ orthopyroxene, $2 \%$ or less spinel, and trace olivine or plagioclase. Grain size varies from medium to coarse. Medium-grained samples have allotriomorphic-granular textures suggesting recrystallization and textural re-equilibration. Coarse-grained samples have porphyroclastic texture with up to $2 \mathrm{~cm}$ clinopyroxene porphyroclasts. Some large clinopyroxene porphyroclasts have exsolved orthopyroxene, but medium-grained clinopyroxene is unexsolved.

The gabbro xenoliths are described in detail by McGuire (1994). In brief, they are spinel-bearing gabbronorites and olivine gabbro. Pyroxenes and spinel are aluminous, and olivine is moderately $\mathrm{Mg}$ rich $\left(\mathrm{Fo}_{69-79}\right)$. Whole rock and mineral compositions suggest the gabbros formed by fractional crystallization from an alkalic mafic parent magma. Thermobarometry indicates crystallization at about $30 \mathrm{~km}$ depth, in the uppermost mantle or lowermost crust beneath Wikieup, and re-equilibration to temperatures of $900-1050{ }^{\circ} \mathrm{C}$ (McGuire 1994). Estimated compressional seismic velocities $\left(\mathrm{V}_{p}\right)$ of the gabbro samples are 6.4 to $7.2 \mathrm{~km} \mathrm{~s}^{-1}$, corrected for temperature and pressure (McGuire 1994). McGuire (1994) concluded, on the basis of petrologic data and comparison with geophysical data for the Wikieup area, that the gabbros formed by basaltic underplating during extension-related magmatism, and are samples from a thin, $<2-\mathrm{km}$ thick, transition zone at the crust-mantle boundary beneath the Transition Zone between the Colorado Plateau and the Basin and Range.

Charnockite xenolith WK1-48 is a medium-grained, granular texture rock and is composed of quartz, orthoclase, plagioclase, orthopyroxene, ilmenite, and glass. The feldspars are perthite and antiperthite, both containing coarse exsolution lamellae of the complimentary feldspar. The glass occurs in rounded pools that mimic grain shapes which suggests that it formed as the result of complete melting (perhaps transport related). Small, equant grains of orthopyroxene line many of the glass pools apparently resulting from either incongruent melting of a pre-existing phase to form glass plus orthopyroxene, or reaction of melt with surrounding minerals to form orthopyroxene.

\section{Analytical methods}

Analytical data for the gabbroic xenoliths and one host basalt sample are presented by McGuire (1994). Mineral compositions of Wikieup spinel peridotites, wehrlites, plagioclase peridotites and pyroxenites were determined by electron microprobe using the 
JEOL 8600 Superprobe at the Texas Center for Superconductivity, University of Houston. Analytical conditions were $15 \mathrm{kV}$ acceleration voltage, $20 \mathrm{nA}$ beam current, focused beam, $40 \mathrm{~s}$ count times except $20 \mathrm{~s}$ on Na. Matrix correction was done by Tracor Northern ZAF. Natural and synthetic mineral standards were used for calibration. Representative mineral compositions are given in Tables 1 to 5 . Errors are approximately $\pm 1-2$ relative $\%$ on major elements, and $\pm 5-10$ relative $\%$ on minor elements. All phases were found to be homogeneous, within error, except for slight zonation in plagioclase in the plagioclase peridotite samples.

Four spinel peridotite, two wehrlite, three plagioclase peridotite, three aluminous pyroxenite xenoliths, the charnokite xenolith, and two samples of Wikieup host basalt were analyzed for whole rock major, trace and rare earth element contents. Basalt and weathering rinds were removed by sawing, and samples were crushed and powdered in a tungsten-carbide ring mill. Owing to the possibility of contamination from the ring mill, $\mathrm{Nb}$ and $\mathrm{Ta}$ data may be suspect. All but one of these samples were analyzed at Washington State University using inductively-coupled plasma mass spectroscopy (ICP-MS; analyst C. Knaack) and standard X-ray fluorescence (XRF; analyst D. Johnson). A number of elements were measured by both methods and the results agree well. Results are given in Tables 6 and 7. Analyses reported XRF results for major elements and $\mathrm{Y}, \mathrm{Sc}, \mathrm{V}, \mathrm{Zr}, \mathrm{Sr}, \mathrm{Zn}, \mathrm{Cu}, \mathrm{Ni}, \mathrm{Cr}, \mathrm{Rb}, \mathrm{Ga}$, and ICP-MS results for rare earth elements (REE) and $\mathrm{Ba}, \mathrm{Th}, \mathrm{Nb}$, $\mathrm{Hf}, \mathrm{Ta}, \mathrm{U}, \mathrm{Pb}, \mathrm{Cs}$. Two samples, WK1-16a and WK2-13, were analyzed at University of Houston by inductively-coupled plasma spectroscopy (ICP), using a Thermo Jarrell Ash ICP spectrometer and methods described by Norman et al. (1989).

Isotopic ratios of $\mathrm{Sr}, \mathrm{Nd}$, and $\mathrm{Pb}$ and elemental concentrations for $\mathrm{Rb}, \mathrm{Sr}, \mathrm{Sm}, \mathrm{Nd}, \mathrm{U}$, and $\mathrm{Pb}$ by isotope dilution have been measured on plagioclase and clinopyroxene mineral separates as well as on whole rocks of alkali basalt and charnockite (Table 8). Sample preparation and column chemistry have followed standard procedures outlined in Mukasa et al. (1987) and Reisberg and Zindler (1986). Isotopic measurements have been carried out on VG Sector thermal ionization mass spectrometers at the University of Michigan. The $\mathrm{Pb}$ isotopic compositions and all isotope dilutions for elemental concentrations have been determined in static mode while the $\mathrm{Nd}$ and $\mathrm{Sr}$ isotopic compositions have been determined multidynamically. $\mathrm{Pb}$ ratios have been corrected for mass fractionation using a factor of 0.11 percent per atomic mass unit $(\mathrm{amu})$ based on replicate analyses of the National Institute of Standards (NIST) sample NBS-981. The correction for U concentration runs is 0.10 percent per amu based on replicate analyses of NIST U standard U-500. The La Jolla Nd standard yields ${ }^{143} \mathrm{Nd} /{ }^{144} \mathrm{Nd}$ values of $0.511842 \pm 10$, and the NIST Sr standard NBS-987 ${ }^{87} \mathrm{Sr} /{ }^{86} \mathrm{Sr}$ values of $0.710246 \pm 12$. Nd ratios have been normalized to ${ }^{146} \mathrm{Nd} /{ }^{144} \mathrm{Nd}$ of 0.721900 , and $\mathrm{Sr}$ ratios to ${ }^{86} \mathrm{Sr} /{ }^{88} \mathrm{Sr}$ of 0.119400 . Errors on concentrations range from 0.1 percent to about 0.9 percent with $\mathrm{U}$ concentrations having the largest. Measured blanks are $100 \mathrm{pg}$ for $\mathrm{Pb}, 20 \mathrm{pg}$ for $\mathrm{Nd}, 25 \mathrm{pg}$ for $\mathrm{Sr}, 15 \mathrm{pg}$ for $\mathrm{Sm}$ and $15 \mathrm{pg}$ for $\mathrm{U}$.

\section{Results}

\section{Mineral compositions}

Compositions of spinel, pyroxene, olivine and feldspar are shown in Tables 1-5. Spinel peridotite mineral compositions are similar to those reported for Cr-diopside group peridotites from other localities, with the exception that the olivine $\left(\mathrm{Fo}_{83}\right.$ to $\left.\mathrm{Fo}_{87}\right)$ is more ironrich than typical for Cr-diopside group peridotites from the southwestern United States (e.g., Mg\# 0.85-0.93; Frey and Prinz 1978; Wilshire et al. 1988, 1991). Wehrlite mineral compositions are transitional between expected compositions for $\mathrm{Cr}$-diopside and $\mathrm{Al}$-augite group peridotites. Spinels have $\mathrm{Mg} \#$ similar to the Wikieup Cr-diopside group spinel peridotites, but $\mathrm{Cr} /$ $(\mathrm{Cr}+\mathrm{Al})$ ratios are lower (Fig. 2). Pyroxenes have higher $\mathrm{Al}$ and $\mathrm{Ti}$ contents than the spinel peridotites, but, lower $\mathrm{Cr}_{2} \mathrm{O}_{3}$ and $\mathrm{Mg} \#$ (Fig. 2). Wehrlite olivines are $\mathrm{Fo}_{76}$ to $\mathrm{Fo}_{83}$, more $\mathrm{Fe}$-rich than the spinel peridotite olivines.

Plagioclase peridotite mineral compositions are lower in $\mathrm{Mg}$ and $\mathrm{Cr}$ and higher in $\mathrm{Al}$ and $\mathrm{Fe}$ than the wehrlites, and similar to the Al-augite group pyroxenites and the gabbroic xenoliths. Spinel in plagioclase peridotites has $\mathrm{Cr} /(\mathrm{Cr}+\mathrm{Al})$ ratios of 0.02 to 0.03 . Pyroxenes are similar in composition to the Al-augite group pyroxenites and the gabbros (Fig. 2). Olivines are $\mathrm{Fo}_{76}$ to $\mathrm{Fo}_{79}$, similar to olivine in the olivine gabbros. Plagioclase is about $\mathrm{Ab}_{43-46}, \mathrm{An}_{50-54}, \mathrm{Or}_{2-4}$, more Na-rich than in the gabbros. Zoning measured on single plagioclase grains shows slight normal zoning with grain rims more sodic than grain centers by only 1 to $2 \% \mathrm{Ab}$.

Mineral compositions in the Al-augite group pyroxenites are nearly indistinguishable from those of the Wikieup gabbroic xenoliths. Spinels are Al-rich with

Table 1 Wikieup mantle xenolith spinel compositions

\begin{tabular}{|c|c|c|c|c|c|c|c|c|c|c|}
\hline \multirow[t]{2}{*}{ Sample no. } & \multicolumn{2}{|c|}{ Spinel peridotite } & \multicolumn{3}{|c|}{ Wehrlite } & \multicolumn{3}{|c|}{ Plagioclase peridotite } & \multicolumn{2}{|c|}{ Al-augite pyroxenite } \\
\hline & WK1-34 & WK2-1a & WK1-3 & WK1-8 & WK2-60 & WK1-24 & WK1-43 & WK1-63 & WK $1-130$ & WK1-49 \\
\hline $\mathrm{SiO}_{2}$ & 0.03 & 0.00 & 0.00 & 0.00 & 0.00 & 0.01 & 0.00 & 0.00 & 0.00 & 0.05 \\
\hline $\mathrm{Al}_{2} \mathrm{O}_{3}$ & 32.48 & 40.69 & 55.88 & 52.37 & 44.95 & 59.91 & 57.58 & 60.99 & 63.24 & 56.95 \\
\hline $\mathrm{FeO}$ & 19.06 & 23.17 & 17.64 & 21.85 & 26.40 & 20.20 & 19.28 & 18.93 & 18.16 & 20.51 \\
\hline $\mathrm{MgO}$ & 14.60 & 14.59 & 17.87 & 15.76 & 13.52 & 17.86 & 17.76 & 16.79 & 18.23 & 16.38 \\
\hline $\mathrm{MnO}$ & 0.22 & 0.21 & 0.15 & 0.17 & 0.22 & 0.15 & 0.15 & 0.14 & 0.11 & 0.16 \\
\hline $\mathrm{TiO}_{2}$ & 0.85 & 0.92 & 0.37 & 0.34 & 0.87 & 0.39 & 0.25 & 0.45 & 0.24 & 0.52 \\
\hline $\mathrm{Cr}_{2} \mathrm{O}_{3}$ & 32.64 & 20.58 & 7.79 & 9.54 & 13.97 & 1.38 & 6.30 & 2.60 & 0.12 & 5.39 \\
\hline $\mathrm{CaO}$ & 0.00 & 0.00 & 0.00 & 0.01 & 0.01 & 0.01 & 0.00 & 0.00 & 0.01 & 0.01 \\
\hline $\mathrm{NiO}$ & 0.21 & 0.26 & 0.37 & 0.24 & 0.24 & 0.27 & 0.28 & 0.26 & 0.19 & 0.27 \\
\hline Total & 100.09 & 100.42 & 100.06 & 100.26 & 100.18 & 100.18 & 101.60 & 100.16 & 100.30 & 100.23 \\
\hline $\mathrm{Cr} /(\mathrm{Cr}+\mathrm{Al})$ & 0.40 & 0.25 & 0.09 & 0.11 & 0.17 & 0.02 & 0.07 & 0.03 & 0.00 & 0.06 \\
\hline $\mathrm{Mg} \#$ & 0.58 & 0.53 & 0.64 & 0.56 & 0.48 & 0.61 & 0.62 & 0.61 & 0.64 & 0.59 \\
\hline
\end{tabular}


Table 2 Wikieup mantle xenolith clinopyroxene compositions

\begin{tabular}{|c|c|c|c|c|c|c|c|c|c|c|}
\hline \multirow[t]{2}{*}{ Sample no. } & \multicolumn{2}{|c|}{ Spinel peridotite } & \multicolumn{3}{|l|}{ Wehrlite } & \multicolumn{3}{|c|}{ Plagioclase peridotite } & \multicolumn{2}{|c|}{ Al-augite pyroxenite } \\
\hline & WK1-29 & WK2-1a & WK1-3 & WK1-8 & WK1-23 & WK1-16a & WK1-24 & WK1-63 & WK1-4 & WK1-49 \\
\hline $\mathrm{SiO}_{2}$ & 51.96 & 50.98 & 49.92 & 50.66 & 48.54 & 48.32 & 49.65 & 49.29 & 48.07 & 48.58 \\
\hline $\mathrm{Al}_{2} \mathrm{O}_{3}$ & 4.62 & 5.07 & 6.84 & 6.05 & 7.20 & 8.43 & 7.36 & 7.49 & 8.53 & 7.46 \\
\hline $\mathrm{FeO}$ & 4.00 & 3.92 & 4.85 & 5.38 & 6.40 & 6.40 & 6.15 & 6.32 & 7.66 & 5.84 \\
\hline $\mathrm{MgO}$ & 16.11 & 14.64 & 14.64 & 14.43 & 14.00 & 13.31 & 14.21 & 13.89 & 12.80 & 14.23 \\
\hline $\mathrm{MnO}$ & 0.11 & 0.09 & 0.12 & 0.14 & 0.15 & 0.16 & 0.16 & 0.15 & 0.18 & 0.14 \\
\hline $\mathrm{TiO}_{2}$ & 0.64 & 0.94 & 1.17 & 0.91 & 1.81 & 2.06 & 1.21 & 1.50 & 1.55 & 1.16 \\
\hline $\mathrm{Cr}_{2} \mathrm{O}_{3}$ & 1.03 & 0.78 & 0.48 & 0.55 & 0.35 & 0.17 & 0.11 & 0.19 & 0.00 & 0.40 \\
\hline $\mathrm{CaO}$ & 21.02 & 22.99 & 21.53 & 21.78 & 21.12 & 20.73 & 20.96 & 20.77 & 19.84 & 21.14 \\
\hline $\mathrm{Na}_{2} \mathrm{O}$ & 0.94 & 0.89 & 0.70 & 0.69 & 0.79 & 0.91 & 0.91 & 0.98 & 1.01 & 0.65 \\
\hline Total & 100.44 & 100.31 & 100.25 & 100.58 & 100.34 & 100.47 & 100.68 & 100.59 & 99.64 & 99.59 \\
\hline En & 0.48 & 0.44 & 0.45 & 0.44 & 0.43 & 0.42 & 0.43 & 0.43 & 0.41 & 0.44 \\
\hline Fs & 0.07 & 0.07 & 0.08 & 0.09 & 0.11 & 0.11 & 0.11 & 0.11 & 0.14 & 0.10 \\
\hline Wo & 0.45 & 0.50 & 0.47 & 0.47 & 0.46 & 0.47 & 0.46 & 0.46 & 0.45 & 0.46 \\
\hline $\mathrm{Mg} \#$ & 0.88 & 0.87 & 0.73 & 0.75 & 0.71 & 0.67 & 0.71 & 0.70 & 0.65 & 0.71 \\
\hline
\end{tabular}

Table 3 Wikieup mantle xenolith orthopyroxene compositions

\begin{tabular}{|c|c|c|c|c|c|c|c|c|c|c|}
\hline \multirow[t]{2}{*}{ Sample no. } & \multicolumn{2}{|c|}{ Spinel peridotite } & \multicolumn{3}{|c|}{ Wehrlite } & \multicolumn{3}{|c|}{ Plagioclase peridotite } & \multicolumn{2}{|c|}{ Al-augite pyroxenite } \\
\hline & WK1-29 & WK2-34 & WK 1-3 & WK $1-8$ & WK $1-70$ & WK1-1a & WK $1-43$ & WK1-63 & WK $1-5 a$ & WK $1-49$ \\
\hline $\mathrm{SiO}_{2}$ & 55.58 & 55.53 & 53.95 & 54.24 & 54.34 & 52.61 & 53.68 & 53.06 & 51.54 & 52.51 \\
\hline $\mathrm{Al}_{2} \mathrm{O}_{3}$ & 3.12 & 2.55 & 4.69 & 4.18 & 4.65 & 5.47 & 5.14 & 5.50 & 5.77 & 5.02 \\
\hline $\mathrm{FeO}$ & 8.44 & 7.63 & 10.09 & 11.29 & 9.52 & 13.63 & 10.79 & 13.22 & 14.85 & 12.18 \\
\hline $\mathrm{MgO}$ & 31.57 & 32.57 & 29.78 & 29.04 & 30.26 & 26.71 & 28.82 & 27.59 & 25.53 & 28.23 \\
\hline $\mathrm{MnO}$ & 0.18 & 0.18 & 0.20 & 0.22 & 0.22 & 0.26 & 0.23 & 0.25 & 0.28 & 0.23 \\
\hline $\mathrm{TiO}_{2}$ & 0.21 & 0.19 & 0.29 & 0.22 & 0.20 & 0.31 & 0.21 & 0.28 & 0.43 & 0.27 \\
\hline $\mathrm{Cr}_{2} \mathrm{O}_{3}$ & 0.53 & 0.52 & 0.25 & 0.20 & 0.33 & 0.09 & 0.22 & 0.09 & 0.00 & 0.21 \\
\hline $\mathrm{CaO}$ & 1.07 & 1.04 & 0.94 & 0.74 & 0.95 & 1.06 & 1.01 & 1.02 & 1.22 & 0.95 \\
\hline $\mathrm{Na}_{2} \mathrm{O}$ & 0.06 & 0.06 & 0.03 & 0.03 & 0.07 & 0.06 & 0.06 & 0.06 & 0.07 & 0.04 \\
\hline Total & 100.74 & 100.26 & 100.21 & 100.16 & 100.53 & 100.21 & 100.170 & 101.09 & 99.68 & 99.64 \\
\hline En & 0.85 & 0.87 & 0.82 & 0.81 & 0.83 & 0.76 & 0.81 & 0.77 & 0.73 & 0.79 \\
\hline Fs & 0.13 & 0.11 & 0.16 & 0.18 & 0.15 & 0.22 & 0.17 & 0.21 & 0.24 & 0.19 \\
\hline Wo & 0.02 & 0.02 & 0.02 & 0.01 & 0.02 & 0.02 & 0.02 & 0.02 & 0.03 & 0.02 \\
\hline $\mathrm{Mg} \#$ & 0.87 & 0.88 & 0.84 & 0.82 & 0.85 & 0.78 & 0.83 & 0.79 & 0.75 & 0.81 \\
\hline Wells $T\left({ }^{\circ} \mathrm{C}\right)^{\mathrm{a}}$ & 993 & 980 & 960 & 926 & 982 & 971 & 992 & 949 & 969 & 960 \\
\hline
\end{tabular}

${ }^{\mathrm{a}}$ Wells (1977)

Table 4 Wikieup mantle xenolith olivine compositions

\begin{tabular}{|c|c|c|c|c|c|c|c|c|c|c|}
\hline \multirow[t]{2}{*}{ Sample no. } & \multicolumn{4}{|c|}{ Spinel peridotite } & \multicolumn{3}{|l|}{ Wehrlite } & \multicolumn{3}{|c|}{ Plagioclase peridotite } \\
\hline & WK1-29 & WK1-34 & WK2-1a & WK2-26 & WK1-3 & WK1-23 & WK1-28 & WK1-1a & WK1-24 & WK1-63 \\
\hline $\mathrm{SiO}_{2}$ & 39.99 & 40.22 & 39.47 & 39.86 & 39.76 & 38.72 & 39.98 & 38.17 & 39.11 & 38.71 \\
\hline $\mathrm{FeO}$ & 13.28 & 12.32 & 15.92 & 14.63 & 16.00 & 22.06 & 17.41 & 22.42 & 19.59 & 21.00 \\
\hline $\mathrm{MgO}$ & 46.73 & 47.14 & 44.96 & 45.63 & 44.85 & 40.04 & 43.57 & 39.55 & 41.78 & 40.45 \\
\hline $\mathrm{MnO}$ & 0.18 & 0.17 & 0.21 & 0.21 & 0.21 & 0.29 & 0.22 & 0.30 & 0.28 & 0.30 \\
\hline $\mathrm{CaO}$ & 0.08 & 0.08 & 0.11 & 0.08 & 0.09 & 0.10 & 0.09 & 0.10 & 0.09 & 0.13 \\
\hline $\mathrm{NiO}$ & 0.28 & 0.35 & 0.26 & 0.30 & 0.32 & 0.11 & 0.24 & 0.15 & 0.18 & 0.18 \\
\hline Total & 100.54 & 100.28 & 100.92 & 100.71 & 101.22 & 101.30 & 101.51 & 100.69 & 101.04 & 100.76 \\
\hline Fo & 0.86 & 0.87 & 0.83 & 0.85 & 0.83 & 0.76 & 0.82 & 0.76 & 0.79 & 0.77 \\
\hline $\mathrm{Fa}$ & 0.14 & 0.13 & 0.17 & 0.15 & 0.17 & 0.24 & 0.18 & 0.24 & 0.21 & 0.23 \\
\hline
\end{tabular}


Table 5 Wikieup plagioclase peridotite feldspar compositions ( $n a$ not analyzed)

\begin{tabular}{lrrlr}
\hline Sample no. & WK1-1a & WK1-16a & WK1-24 & WK1-63 \\
\hline $\mathrm{SiO}_{2}$ & 53.86 & 56.21 & 54.01 & 54.50 \\
$\mathrm{Al}_{2} \mathrm{O}_{3}$ & 29.50 & 27.59 & 29.06 & 29.12 \\
$\mathrm{FeO}$ & 0.16 & 0.58 & na & 0.21 \\
$\mathrm{MgO}$ & 0.03 & 0.19 & na & 0.02 \\
$\mathrm{CaO}$ & 11.14 & 9.12 & 10.95 & 10.88 \\
$\mathrm{Na}{ }_{2} \mathrm{O}$ & 4.89 & 5.95 & 5.11 & 5.12 \\
$\mathrm{~K}_{2} \mathrm{O}$ & 0.42 & 0.60 & 0.44 & 0.46 \\
$\mathrm{Total}$ & 100.01 & 100.25 & 99.57 & 100.31 \\
$\mathrm{Ab}$ & 0.43 & 0.52 & 0.46 & 0.45 \\
$\mathrm{An}$ & 0.54 & 0.44 & 0.50 & 0.53 \\
$\mathrm{Or}$ & 0.02 & 0.04 & 0.04 & 0.03 \\
\hline
\end{tabular}

$\mathrm{Cr} /(\mathrm{Cr}+\mathrm{Al})$ ratios of 0.001 to 0.06 . Pyroxenes are aluminous with low $\mathrm{Cr}$ contents. Olivines in the gabbros are $\mathrm{FO}_{70}$ to $\mathrm{FO}_{79}$ and plagioclase anorthite contents range from $\mathrm{An}_{50}$ to $\mathrm{An}_{70}$.

Geothermometry, using the Wells (1977) two pyroxene thermometer, indicates equilibration temperatures of $925-990{ }^{\circ} \mathrm{C}$ (Table 3) with no significant differences

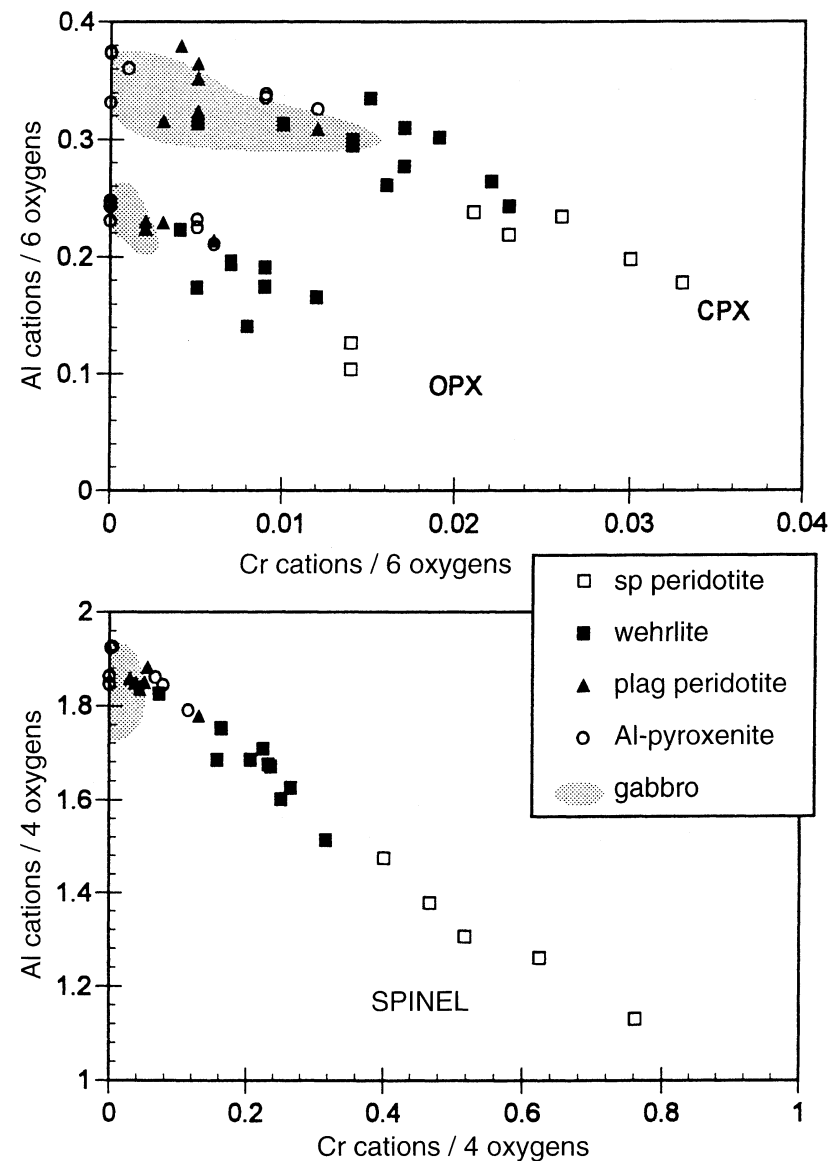

Fig. $2 \mathrm{Cr}$ and $\mathrm{Al}$ cation contents of Wikieup mantle xenolith spinels and pyroxenes. Open square $\mathrm{Cr}$-diopside group spinel peridotite, filled square wehrlite, filled triangle plagioclase peridotite, open circle Alaugite group clinopyroxenite, stippled field gabbros (from McGuire 1994) in temperature between any of these rock types. This temperature range is well within the $900-1050{ }^{\circ} \mathrm{C}$ range estimated for the Wikieup gabbro xenoliths (McGuire 1994). Pressures can not be calculated from the Wikieup mineral assemblages, but can be estimated using the calculated temperatures and a geotherm projected for the known surface heat flow in the region. Equilibrium geotherms for the regional surface heat flow of 90 $100 \mathrm{mWm}^{-2}$ (Sass et al. 1994), place the mantle xenoliths $\left(925-990{ }^{\circ} \mathrm{C}\right)$ at about 25 to $35 \mathrm{~km}$ depth. Geophysical models for the area estimated the depth of the crust-mantle transition to be $27-30 \mathrm{~km}$ depth. This suggests the Wikieup mantle xenoliths originated in the uppermost mantle near or within the crust-mantle transition zone. This depth range is compatible with the absence of garnet and the presence of plagioclase in the peridotites and pyroxenities at the estimated temperatures.

\section{Whole rock compositions}

Whole rock major element compositions (Table 6) show a continuous range; $\mathrm{MgO}$ contents are highest in spinel peridotites, slightly lower in wehrlites and, in plagioclase lower yet peridotites, with $\mathrm{Al}$-augite group pyroxenites containing the lowest Mgo concentrations of the ultramafic rocks. Gabbro $\mathrm{MgO}$ contents vary widely and overlap with plagioclase peridotites and Al-augite pyroxenites. The host alkali basalts have $\mathrm{MgO}$ contents (9.1-10.2 wt\%) overlapping with the lower end of the range for gabbro xenoliths, but falling below the values for the pyroxenites. Whole rock $\mathrm{MgO}$ contents show correlations with mineral compositions. Forsterite content and whole rock wt $\% \mathrm{MgO}$ are positively correlated (Fig. 3) for all Wikieup xenoliths. Likewise, spinel and pyroxene $\mathrm{Cr}$ contents are positively correlated, and $\mathrm{Al}$ contents are negatively correlated, with whole rock $\mathrm{MgO}$. Whole rock $\mathrm{MgO}$ correlates positively with whole rock concentrations of compatible elements such as $\mathrm{Cr}$, $\mathrm{Ni}$, and is inversely correlated with $\mathrm{Si}, \mathrm{Ca}, \mathrm{Al}, \mathrm{Ti}$, and incompatible elements such as $\mathrm{Na}, \mathrm{K}, \mathrm{P}, \mathrm{Rb}, \mathrm{Y}, \mathrm{Sr}, \mathrm{Hf}$, $\mathrm{Th}, \mathrm{Pb}$ and the REE elements (Fig. 4). Compatible element $(\mathrm{Mg}, \mathrm{Cr}, \mathrm{Ni})$ concentrations are higher, and incompatible element ( $\mathrm{Sr}, \mathrm{Ca}, \mathrm{Zr}, \mathrm{Na}, \mathrm{K}, \mathrm{P}, \mathrm{Rb}, \mathrm{U}, \mathrm{Pb}$, Cs, Th, REE) concentrations are lower, in the gabbros and pyroxenites than in the host alkali olivine basalt (Table 7).

Rare earth element patterns are generally flat or slightly light rare earth element (LREE) enriched and their abundances correlate with rock type and major element composition (Fig. 5). The spinel peridotite samples, with the highest $\mathrm{MgO}$ contents, have the lowest REE abundances; the wehrlites have the second lowest REE abundances, and plagioclase peridotite, and the Alaugite pyroxenites have the highest values.

Gabbro REE abundances overlap those of the pyroxenites and plagioclase peridotites. All gabbro REE patterns, and one of the plagioclase peridotite samples, 


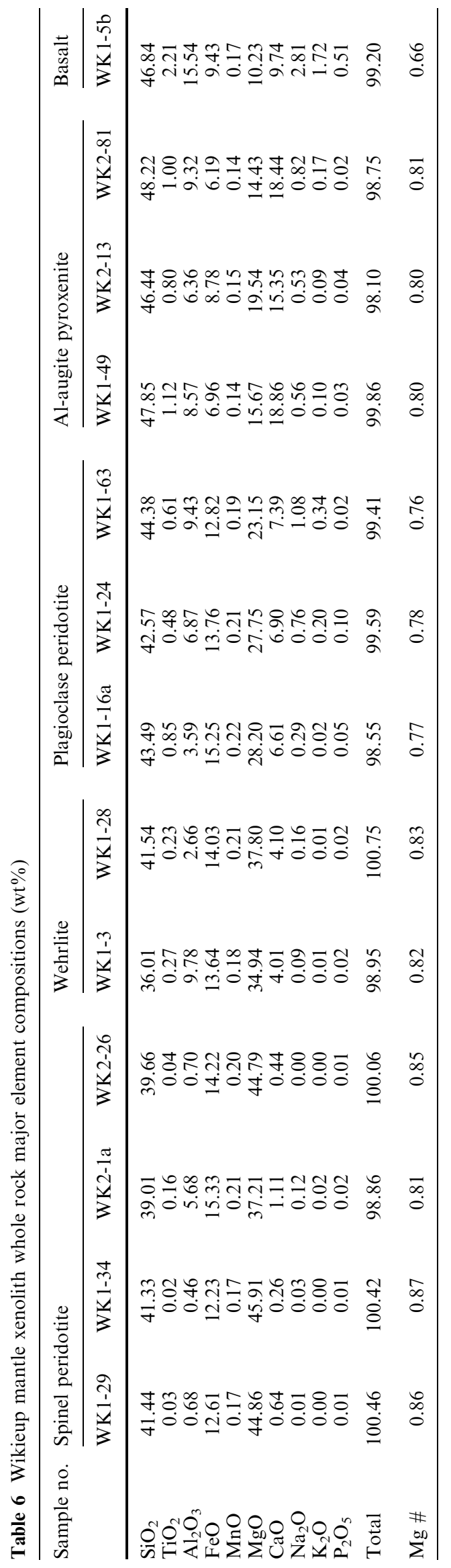

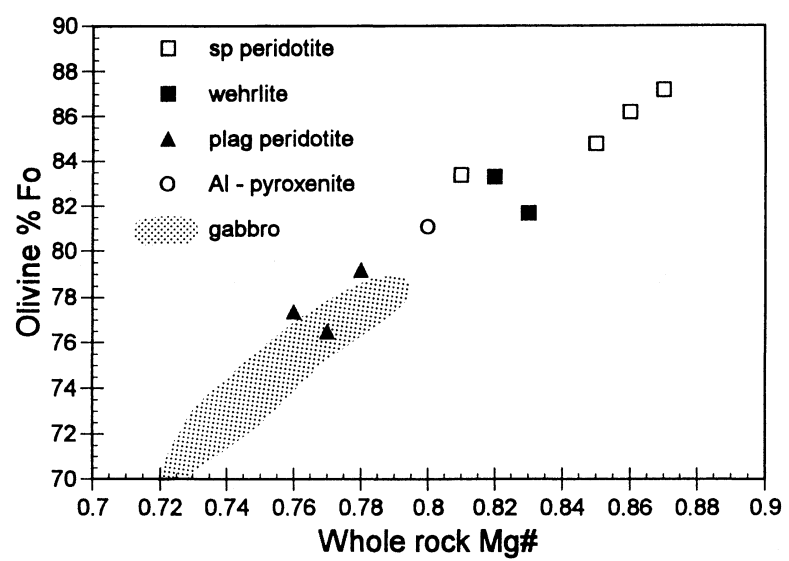

Fig. 3 Bulk rock Mg\# versus olivine forsterite content. Symbols as in Fig. 2

exhibit slight positive $\mathrm{Eu}$ anomalies (Eu/Eu* of 1.1-1.9), and samples with greater $\mathrm{Eu}$ anomalies have higher REE abundances and lower $\mathrm{MgO}$ contents. Wehrlite and plagioclase periodtite REE patterns exhibit slight "spoon-shaped" patterns with the normalized La abundance greater than $\mathrm{Ce}$, and abundances increasing from Ce to $\mathrm{Eu}$ (Fig. 5). This "spoon-shaped" REE pattern is observed in peridotite mantle xenoliths and peridotite massif samples from other localities around the world, and is generally considered to be indicative of metasomatic alteration of mantle peridotite (Navon and Stolper 1987; Takazawa et al. 1992). Host alkali olivine basalt REE patterns are strongly LREE enriched and exhibit higher abundances than any of the xenoliths. McGuire (1994) demonstrated that the gabbro REE patterns are compatible with formation of the gabbros by varying degrees of crystal fractionation from a mafic magma with a REE pattern similar to the host alkali basalt.

\section{Isotopic compositions}

Elemental concentrations of $\mathrm{U}, \mathrm{Pb}, \mathrm{Rb}, \mathrm{Sr}, \mathrm{Sm}$ and $\mathrm{Nd}$ by isotope dilution and isotopic compositions of $\mathrm{Sr}, \mathrm{Pb}$ and $\mathrm{Nd}$ are presented in Table 8 and plotted on diagrams in Figs. 6 to 9. The concentrations of $\mathrm{Pb}, \mathrm{Rb}$ and $\mathrm{U}$ are particularly low in the pyroxene separates, but at least for $\mathrm{Pb}$, reasonably high in the plagioclase separates and whole-rock samples. The amount of $\mathrm{Pb}$ that is due to the procedural blank for the plagioclase analyses is between 0.5 and $4.0 \%$ of the total sample and in whole rocks between 0.3 and 1.0 percent, both contrasting with the values of up to $27 \%$ for the blank $\mathrm{Pb}$ in pyroxene samples. For pyroxene, therefore, we are reporting $\mathrm{Pb}$ isotopic data only for the analysis in which the blank $\mathrm{Pb}$ is only $3 \%$ of the total sample. Blanks of 20 and $25 \mathrm{pg}$ for the analyzed $\mathrm{Nd}$ and $\mathrm{Sr}$, respectively, are small compared to the total amount of sample in each case, and therefore, all values we have measured are reported and are considered to be robust. 

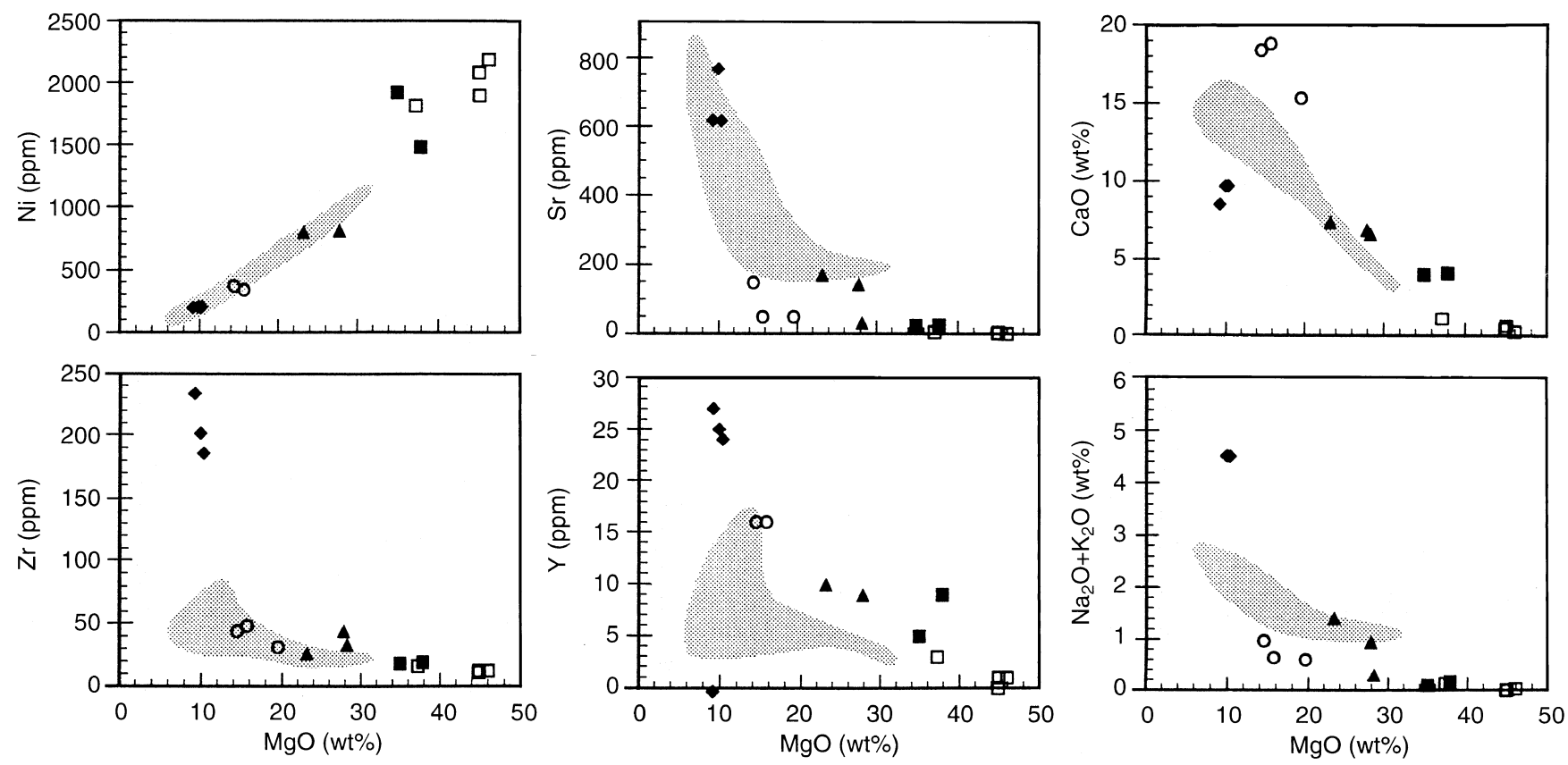

Fig. 4 Selected bulk rock major and trace elements plotted against bulk rock MgOwt\%. Symbols as in Fig. 2; filled diamonds Wikieup host alkali olivine basalts

Covariation diagrams in Figs. 6a and 6b show that the $\mathrm{Pb}$ isotopic compositions of Wikieup alkali basalts are fairly uniform, but that plagioclase mineral separates from the gabbroic xenoliths cover a relatively wide range that overlaps with the data for all other rock types. The $\mathrm{Pb}$ data for all rock types define a small cluster that straddles the Northern Hemisphere Reference Line (NHRL) but is skewed toward more radiogenic ${ }^{207} \mathrm{~Pb} /{ }^{204} \mathrm{~Pb}$ and ${ }^{208} \mathrm{~Pb} /{ }^{204} \mathrm{~Pb}$ values. This cluster falls within the field for Basin and Range basalts, but also overlaps with the fields for the Colorado Plateau xenoliths and Transition Zone basalts. Charnockite sample WK1-48 with a granulitic texture has considerably less radiogenic ${ }^{206} \mathrm{~Pb} /{ }^{204} \mathrm{~Pb}$, but similar ${ }^{207} \mathrm{~Pb} /{ }^{204} \mathrm{~Pb}$ and ${ }^{208} \mathrm{~Pb} /{ }^{204} \mathrm{~Pb}$., It falls in the field for Kilbourne Hole granulites only in the ${ }^{208} \mathrm{~Pb} /{ }^{204} \mathrm{~Pb}$ versus ${ }^{206} \mathrm{~Pb} /{ }^{204} \mathrm{~Pb}$ diagram (Fig. 6b).

The ${ }^{143} \mathrm{Nd} /{ }^{14} \mathrm{Nd}$ versus ${ }^{87} \mathrm{Sr} /{ }^{86} \mathrm{Sr}$ covariation diagram in Fig. 7 shows these ratios to be remarkably uniform for all Wikieup samples. This is in spite of the fact that corresponding ${ }^{147} \mathrm{Sm} /{ }^{144} \mathrm{Nd}$ values for the samples, even of the same mineral type, cover a significantly wide range (Fig. 8). There is no overlap in ${ }^{147} \mathrm{Sm} /{ }^{144} \mathrm{Nd}$ values for the gabbro pyroxene and plagioclase mineral separates on the diagram and this is because of differences in partition coefficients for Sm and $\mathrm{Nd}$ between the two minerals and a common parental magma (e.g., Drake and Weill 1975; Green 1994). ${ }^{143} \mathrm{Nd} /{ }^{144} \mathrm{Nd}$ values for all clinopyroxene-plagioclase mineral pairs are indistinguishable with analytical errors, but for ${ }^{87} \mathrm{Sr} /{ }^{86} \mathrm{Sr}$ mineral pairs in plagioclase peridotite WK1-24 and gabbro WK1-22 exhibit some inexplicable non-equilibrium. Charnockitic sample
WK1-48 has considerably more radiogenic Sr and less radiogenic $\mathrm{Nd}$ compared to the rest of the Wikieup xenoliths (Fig. 7), and also falls below the flat trend defined by all other Wikieup samples on the ${ }^{143} \mathrm{Nd} /{ }^{144} \mathrm{Nd}$ versus ${ }^{147} \mathrm{Sm} /{ }^{144} \mathrm{Nd}$ diagram in Fig. 8. It has $\mathrm{Sm} / \mathrm{Nd}$ model ages, based on depleted mantle evolution $\left(\mathrm{T}_{\mathrm{DM}}\right)$ and bulk silicate earth evolution $\left(\mathrm{T}_{\mathrm{CHUR}}\right)$, of $1240 \mathrm{Ma}$ and $896 \mathrm{Ma}$, respectively.

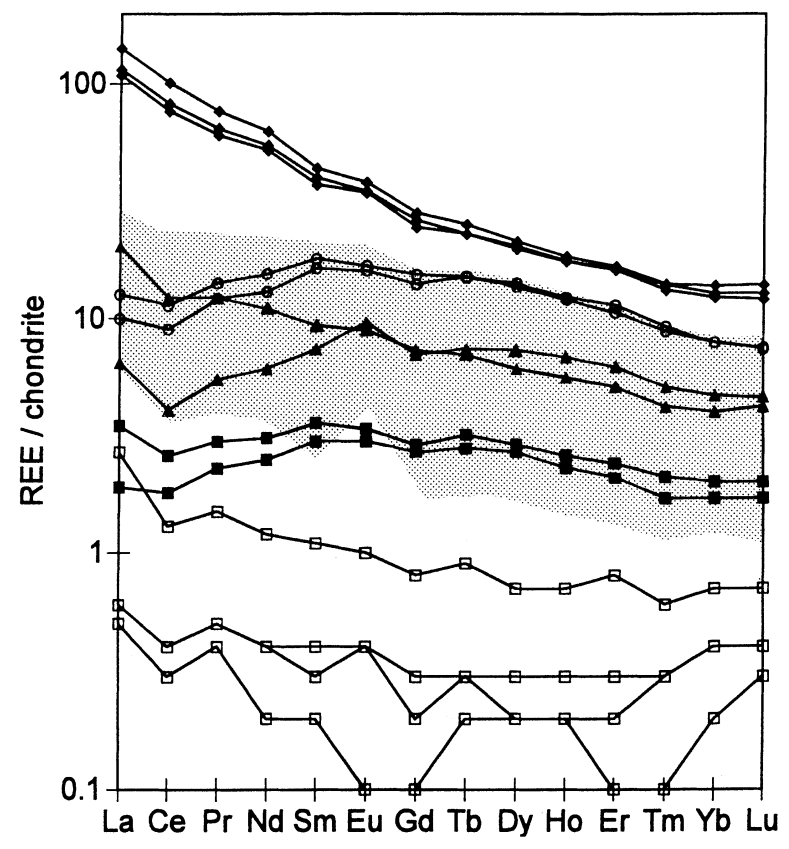

Fig. 5 Whole rock rare earth abundances, normalized to chondritic values of Evensen et al. (1978). Symbols as in Fig. 4 


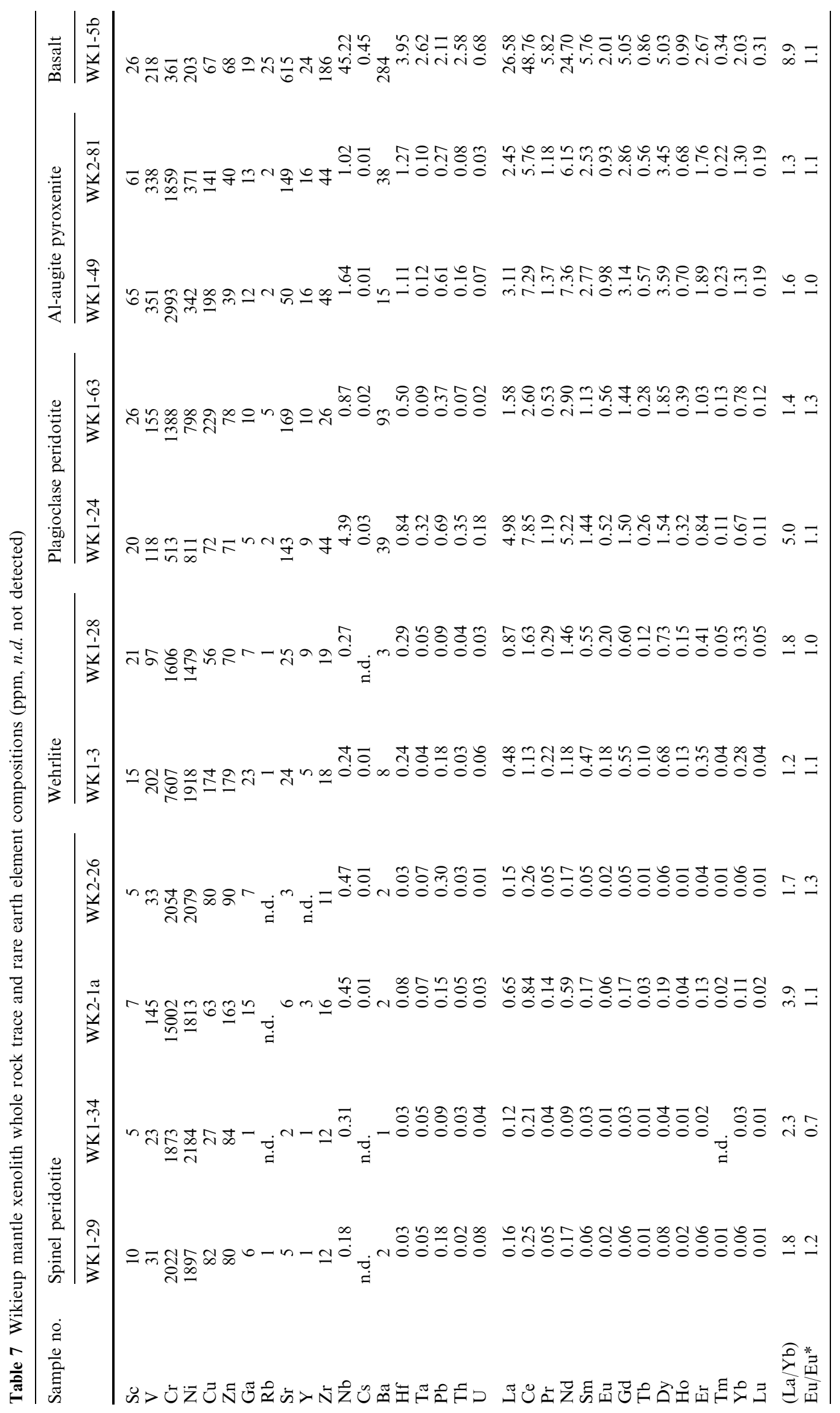




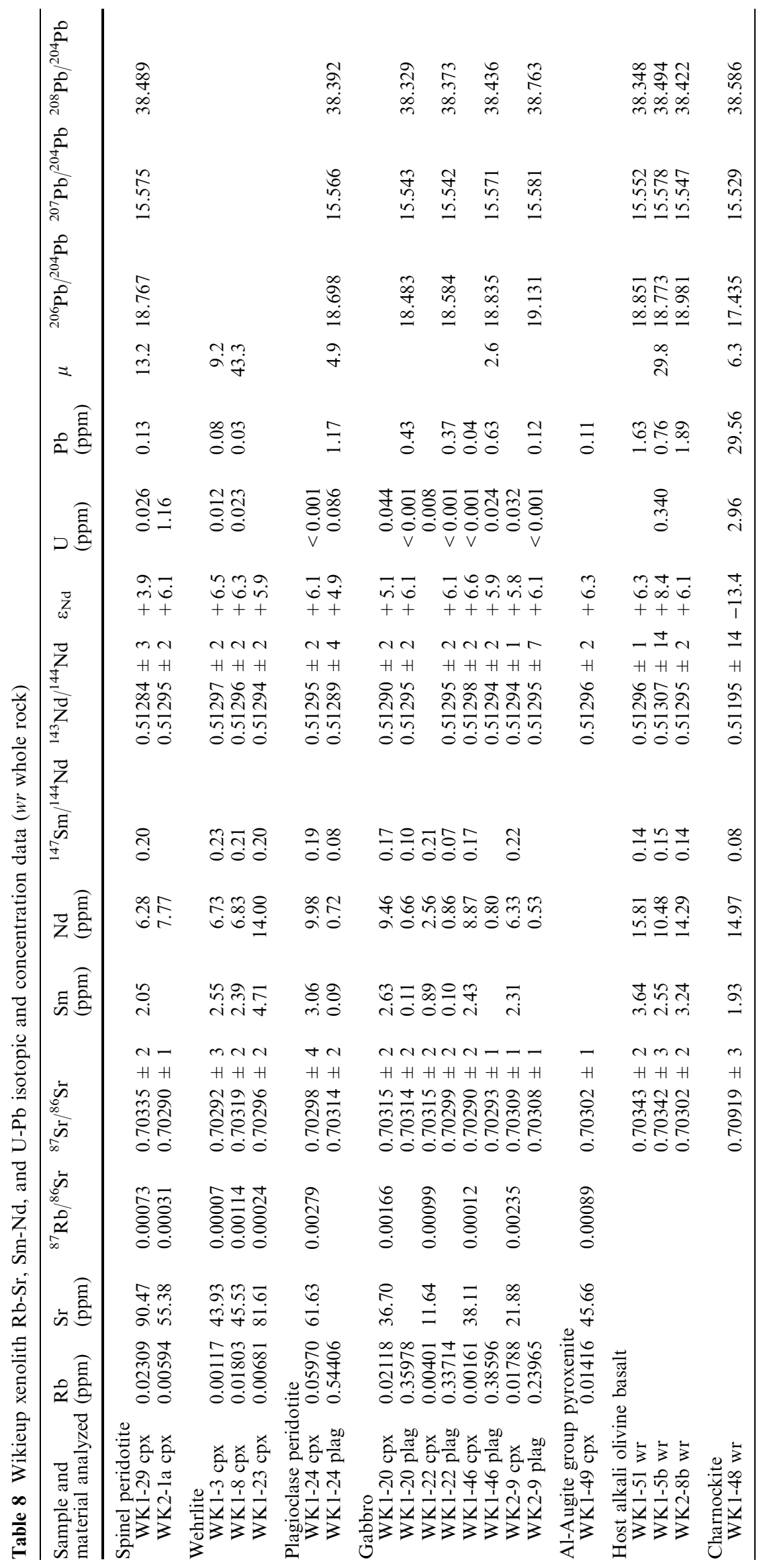




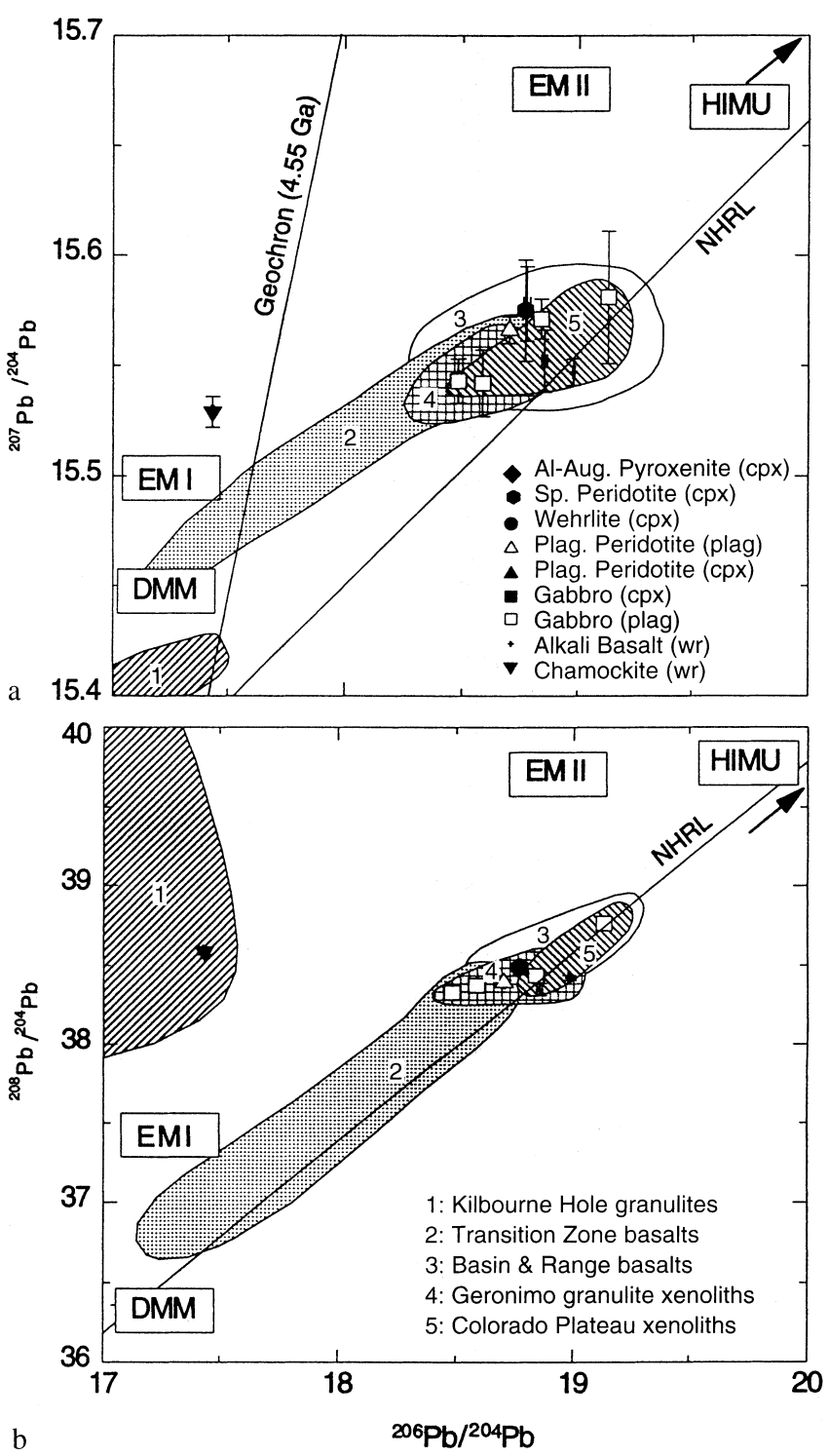

Fig. 6 a ${ }^{207} \mathrm{~Pb} /{ }^{204} \mathrm{~Pb}$ versus ${ }^{206} \mathrm{~Pb} /{ }^{204} \mathrm{~Pb}$ and $\mathbf{b}{ }^{208} \mathrm{~Pb} /{ }^{204} \mathrm{~Pb}$ versus ${ }^{20} \mathrm{~Pb} /{ }^{204} \mathrm{~Pb}$ covariation diagrams on which the data for xenoliths and host lavas from Wikieup are compared to the fields for xenoliths and basalts from localities in the Basin and Range (Bradshaw et al. 1993; Farmer et al. 1989; Kempton et al. 1990, 1991; Menzies et al. 1985) and Colorado Plateau (Esperança et al. 1988; Kempton et al. 1991; Smith et al. 1994) provinces as well as the Transition Zone (Kempton et al. 1991) and the Rio Grande rift (Johnson and Thompson 1991; Perry et al. 1987; Reid et al. 1982; Roden et al. 1988). The mantle endmembers DMM, EM I, EM II and HIMU are from Zindler and Hart (1986), and the northern hemisphere reference line (NHRL) is from Hart (1984). Symbols on the diagram are also used in Figs. 7-9. Note that there are no $\mathrm{Pb}$ isotopic data for clinopyroxene in Al-augite pyroxenite, gabbro or wehrlite, but that symbols are included in the legend because of the $\mathrm{Nd}$ and $\mathrm{Sr}$ data plotted in Figs. 7 and 8

\section{Discussion}

The relatively uniform isotopic compositions of the Wikieup xenoliths suggest a common petrogenesis for these rock types. Mineral and whole rock compositional trends are consistent with this hypothesis. Furthermore,

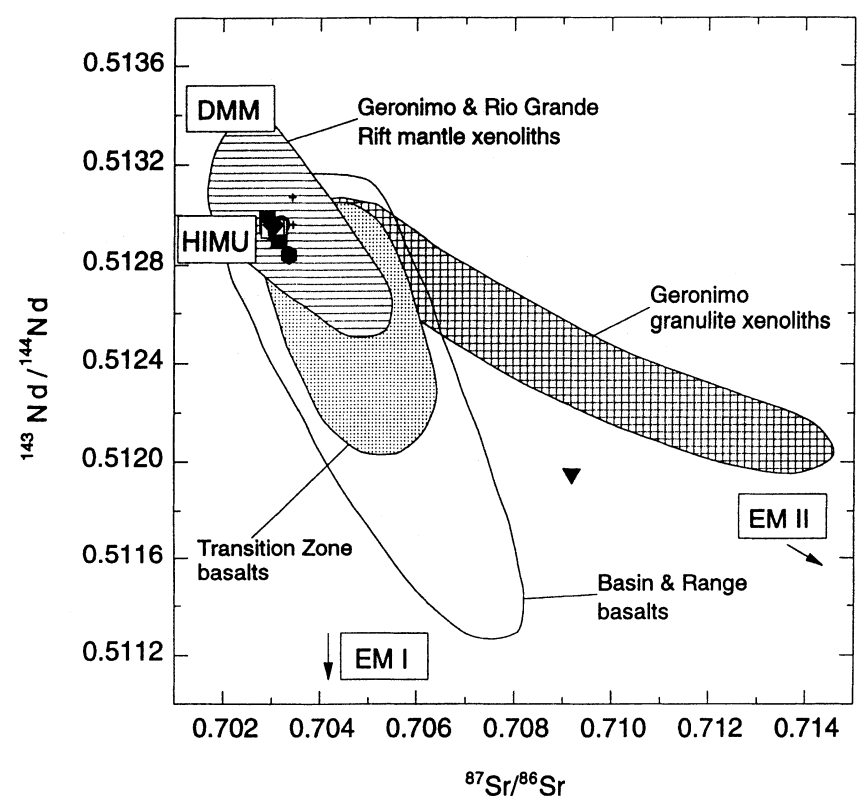

Fig. $7{ }^{143} \mathrm{Nd} /{ }^{144} \mathrm{Nd}$ versus ${ }^{87} \mathrm{Sr} /{ }^{86} \mathrm{Sr}$ diagram showing the remarkable uniformity of Wikieup xenoliths and lavas when compared to fields for other localities in the Basin and Range province, Transition Zone and Rio Grande Rift. Symbols and data sources as in Fig. 6

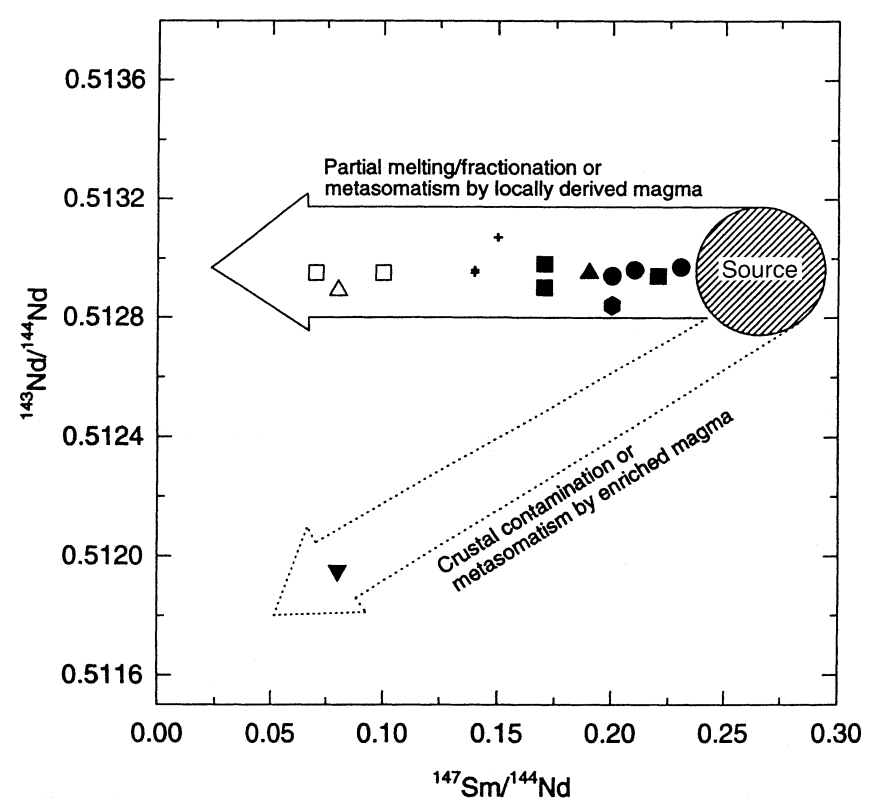

Fig. $8 \mathrm{Sm}-\mathrm{Nd}$ isochron diagram showing the "zero-age" trend defined by mineral separates from nearly all Wikieup xenoliths and the host lavas; only a charnockite sample of lower crustal origin falls below this trend. See text for discussion. Symbols as in Fig. 6

the flat trend on the ${ }^{143} \mathrm{Nd} /{ }^{144} \mathrm{Nd}$ versus ${ }^{147} \mathrm{Sm} /{ }^{144} \mathrm{Nd}$ diagram (Fig. 8) indicates lack of radiogenic Nd growth, and therefore that the samples are all very young. The observed composition trends and similarly in isotopic values suggest that the Wikieup xenoliths are related either (a) by crystal fractionation from a magma similar to the host alkali basalt to produce the sequence of rock 
types observed in this xenolith suite, or (b) by a partial melting processes with partial melting of the peridotites producing the basalts, gabbros and pyroxenites, or (c) these rocks may be related by a melt infiltration and metasomatism process with infiltration of mafic magma and rock/magma interactions producing the observed compositional trends and equilibration of isotopic values. The isotopic data themselves are unable to distinguish between these three models, and the petrographic and compositional data must be examined instead.

\section{Crystal fractionation}

The Wikieup gabbros are considered to have formed by crystal fractionation from an alkalic magma similar in composition to the Wikieup host alkali olivine basalt (McGuire 1994). The mineralogy and compositions of the Wikieup Al-augite group clinopyroxenite xenoliths are also consistent with an origin by fractional crystallization, at high pressure, from an alkali magma. The observed compositional trends and similar isotopic values might be interpreted as a crystal fractionation trend suggesting that all the Wikieup xenoliths are comagmatic and formed by crystal fractionation from a magma similar to the host basalt. However, the olivine-rich mineralogy of the spinel peridotities and wehrlites is inconsistent with crystal fractionation from alkali basalt at high pressure. Numerous composite xenoliths at Wikieup indicate all these lithologies coexisted in time and space. Composite xenolith structure repeatedly shows spinel peridotite, wehrlite, and plagioclase peridotite to be the mantle wallrock into which pyroxenite and gabbro veins have been intruded, but the wallrock types are not found in veining intrusive relationships with each other at Wikieup. This physical evidence suggests that Wikieup spinel peridotite, wehrlite, and plagioclase peridotite xenoliths represent mantle wallrock lithologies, and only pyroxenite and gabbro at this locality have originated by crystal fractionation from magmas in the upper mantle.

\section{Partial melting}

While similarities in isotopic compositions for the peridotites and gabbros could be used to argue in favor of melting having produced the latter from the former, the petrographic data show that there is not a simple partial melting relationship to tie the two genetically. The veining relationships observed in Wikieup composite xenoliths consistently show the gabbro and pyroxenite parent magma to be intrusive into the peridotite, and thus not derived from the peridotite. Olivines in the peridotites are more Fe-enriched than is commonly the case for $\mathrm{Cr}$-diopside group peridotites. This suggests that melts from which the gabbros formed were out of chemical equilibrium with the peridotites, and are responsible for introducing the Fe enrichment.

\section{Melt infiltration and metasomatism}

The Wikieup xenolith compositional trends may represent mixing lines between spinel peridotite mantle wallrock and a mafic magma which has intruded and interacted with the mantle wallrock, causing metasomatism and altering its composition to varying degrees. Those samples closest in composition to the spinel peridotite (i.e., wehrlite) have experienced less interaction with the infiltrating magma and those compositions (i.e., plagioclase peridotite) closer to the compositions of the basalt and its cumulates (pyroxenite and gabbro) have experienced a greater degree of interaction and metasomatic alteration. The slight variation in spinel peridotite compositions lies along the plagioclase peridotite-wehrlite-spinel peridotite compositional trends, and taken with the iron-rich olivine compositions of the peridotites, suggests that the spinel peridotites themselves have experienced a small degree of cryptic metasomatic modification.

The observed mineralogy suggests that magma infiltration and reaction with spinel peridotite caused the reaction of primary $\mathrm{Cr}$-rich orthopyroxene and $\mathrm{Cr}$ diopside to $\mathrm{Cr}$-Al-bearing augite; the greater the degree of reaction, the lower the $\mathrm{Cr}$ and higher the $\mathrm{Al}$ content of the resulting clinopyroxene (Fig. 2). Spinel reacted, decreasing the $\mathrm{Cr} /(\mathrm{Cr}+\mathrm{Al})$ ratio (Fig. 2) with increasing degree of metasomatism. Olivine compositions are increasingly iron-rich with increasing degree of reaction (Fig. 3). The plagioclase peridotites are nearly identical in whole rock and mineral composition to the gabbro cumulates, implying that they are the most reacted samples and had the highest metasomatic fluid/ rock ratios, whereas the wehrlites may have formed under conditions of lower metasomatic fluid/rock ratio. The isotopic signatures of Wikieup samples, therefore, are the result of mutual exchange between melts in transport through and in reaction with mantle lithosphere.

Assumptions have to be made in order to deploy binary mixing equations (e.g., Langmuir et al. 1978; DePaolo 1981) to calculate the degree of interaction between the melt and the various mantle rocks. We have assumed that an alkali basaltic melt with ${ }^{147} \mathrm{Sm} /{ }^{144} \mathrm{Nd}$ of $0.14,{ }^{143} \mathrm{Nd} /{ }^{144} \mathrm{Nd}$ of 0.51300 , and $\mathrm{Sm}$ and $\mathrm{Nd}$ concentrations of 3.1 and $13.5 \mathrm{ppm}$, respectively, comprises one end member, and that an average continental spinel lherzolite (McDonough 1990) with ${ }^{147} \mathrm{Sm} /{ }^{144} \mathrm{Nd}$ of 0.26 , ${ }^{143} \mathrm{Nd} /{ }^{144} \mathrm{Nd}$ of 0.51300 , and $\mathrm{Sm}$ and $\mathrm{Nd}$ concentrations of 0.3 and $1.5 \mathrm{ppm}$ comprises the other. We estimate that 40 to $60 \%$ of the $\mathrm{Sm}$ and $\mathrm{Nd}$ in the mantle rock clinopyroxenes is melt-derived. While these minimum and maximum values broadly correspond with the least and most reacted rocks, as determined from petrologic criteria, they do not represent the actual melt to rock ratio. 
Characteristics of the infiltrating magma

All compositional trends for the Wikieup plagioclase peridotite and wehrlite suggest that the metasomatic fluid responsible for their formation was an alkalic mafic magma similar in composition to the Wikieup host alkali olivine basalt. Isotopic compositions suggest that a common source is likely for both the Wikieup host alkali basalt and the alkalic magmas responsible for crystallization of the gabbros and pyroxenites and for infiltration and metasomatism of the Wikieup upper mantle. The evidence for lack of radiogenic Nd growth (Fig. 8) indicates that the samples are very young. Crystallization of gabbro and pyroxenite within magma-filled mantle veins, and wallrock metasomatism by infiltrating magma, probably occurred shortly before the samples were excavated and transported to the surface. The magmas responsible for vein formation and wallrock metasomatism formed early in the same magmatic episode that generated the magmas transporting the Wikieup xenoliths to the surface.

The ${ }^{143} \mathrm{Nd} /{ }^{144} \mathrm{Nd}$ versus ${ }^{147} \mathrm{Sm} /{ }^{144} \mathrm{Nd}$ diagram (Fig. 8) shows that crustal contamination of the Wikieup magmas was at best minimal. In fact, the ${ }^{143} \mathrm{Nd} /{ }^{144} \mathrm{Nd}$ versus ${ }^{206} \mathrm{~Pb} /{ }^{204} \mathrm{~Pb}$ covariation diagram (Fig. 9) shows that the samples lie close to the field for normal mid-ocean ridge basalt (N-MORB), and are displaced only minimally toward the data point for the charnockite, near the EMI endmember (Zindler and Hart 1986) composition, though it could also be argued that this feature was acquired in the mantle lithosphere.

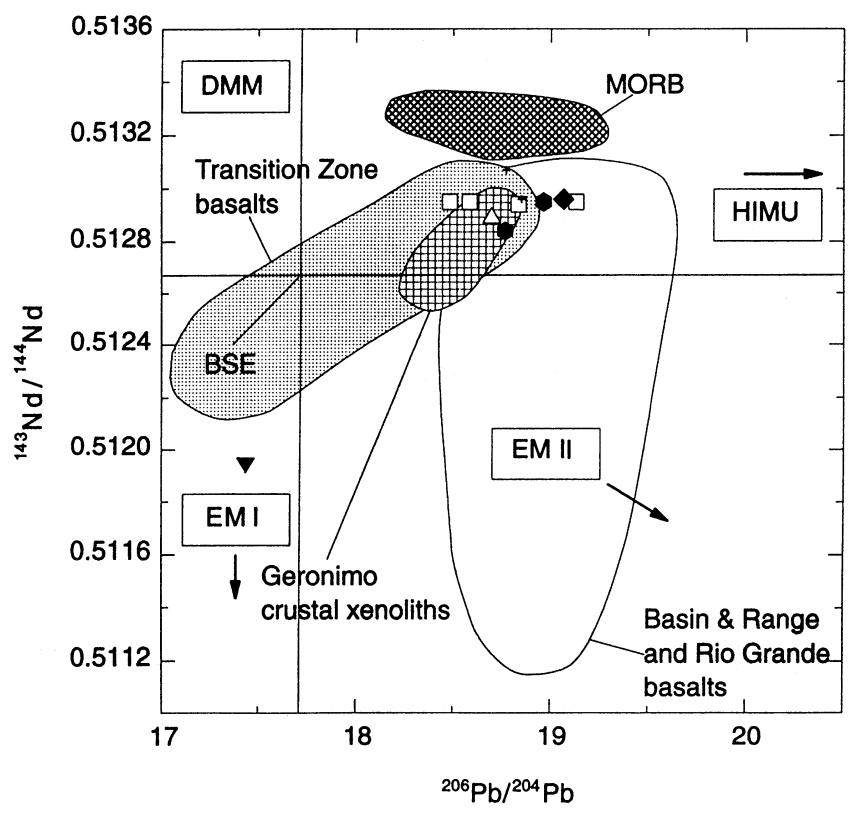

Fig. $9{ }^{143} \mathrm{Nd} /{ }^{144} \mathrm{Nd}$ versus ${ }^{206} \mathrm{~Pb} /{ }^{204} \mathrm{~Pb}$ diagram showing the small variations in $\mathrm{Nd}$ compared to $\mathrm{Pb}$, closeness of the data points to the MORB field and the dissimilarity of the Wikieup xenoliths and basalts to the majority of the Transition Zone basalts, which trend toward the EM I endmember. BSE is bulk silicate earth. Symbols and data sources as in Fig. 6
The $\mathrm{Pb}$ isotopic compositions of the Wikieup alkali basalts and gabbroic and peridotitic xenoliths (Figs. 6a,b) resemble those of the basalts erupted through thinned lithosphere of the Basin and Range province. In this regard, they are different from other Transition Zone basalts which define a field elongated toward EMI or DM on the $\mathrm{Pb}$ covariation diagrams in Figs. 6a and 6b, and toward EMI on the ${ }^{143} \mathrm{Nd} /{ }^{144} \mathrm{Nd}$ versus ${ }^{206} \mathrm{~Pb} /{ }^{204} \mathrm{~Pb}$ diagram in Fig. 9; they are different also from the Geronimo metacumulate xenoliths studied by Kempton et al. (1990). Sr and $\mathrm{Nd}$ isotope ratios fall within the range of values reported for peridotite xenoliths from the Geronimo Volcanic Field (Menzies et al. 1985). All three figures also show that charnockite sample WK1-48 has $\mathrm{Pb}$ and $\mathrm{Nd}$ isotopic characteristics similar to EMI, and is therefore a good candidate for the material variably incorporated into magmas derived from a MORB-type source to produce the elongated fields for the Transitional Zone basalts. Wikieup samples have very little if any EMI contamination likely to reside in the lower crust, and instead might have developed their small isotopic variability entirely within the mantle.

\section{Conclusions}

The petrographic and compositional data from Wikieup mantle xenoliths is most consistent with a model of magmatic modification of upper mantle peridotite by intruding and infiltrating alkali magmas similar to and possibly related to the Wikieup host alkali olivine basalt. Varying degrees of magma-peridotite interaction have produced modification ranging from only slight $\mathrm{Fe}$-enrichment of peridotite olivine compositions to reaction of Cr-rich pyroxenes to produce Al-rich clinopyroxene and a wehrlite mineral assemblage, to high degrees of magma-peridotite reaction producing plagioclase peridotites. Major, trace, and rare earth element trends are all compatible with such a hypothesis, and the uniform isotopic composition of these rock types supports a common petrogenesis.

Isotopic signatures of the Wikieup basalts and xenoliths have $\mathrm{Nd}$ and $\mathrm{Sr}$ isotopic ratios in the range of values known for both Transition Zone and Basin and Range basalts, and similar to values reported for Basin and Range and Rio Grande Rift mantle xenoliths. Lead isotopic values more closely resemble Basin and Range values than Transition Zone values. Similarities between host basalt isotopic ratios and those of the mantle xenoliths suggests that, even at slight degrees of magmaperidotite interaction, isotopic exchange occurred and peridotite isotopic values were modified.

Interaction between ascending mafic magmas and the Transition Zone upper mantle produced significant modification of the upper mantle. Mineral assemblages have changed, and major, trace element, and isotopic compositions are modified. Changes in mineral assemblage and mineral compositions may have significant 
impacts on seismic properties of the upper mantle in this region. Modification of olivine to more Fe-rich compositions will lower seismic velocity of upper mantle peridotite (Chung 1971). Introduction of plagioclase, modification of pyroxene compositions from $\mathrm{Cr}$-rich pyroxenes to Al-rich augite, and increase of the pyroxene/olivine modal ratio may also lower density and contribute to lower seismic velocity (Christensen and Fountain 1975; Kumazawa 1969). The Wikieup xenoliths demonstrate mineralogic and compositional modifications consistent with the modelled, lower than normal, seismic velocities in the uppermost mantle in this region. Magmatic intrusion and infiltration in the Transition Zone upper mantle may also contribute to elevated geothermal gradient, increased heat flow, and higher elevations by heating and lowering density of the lithospheric mantle.

Acknowledgements The authors wish to thank Howard Wilshire for introducing them to this locality and for many stimulating discussions. The manuscript has benefitted from constructive reviews by Brian Beard and an anonymous reviewer. Sample preparation efforts of Ron Nhim, Trung Nguyen, and Thong Pham are appreciated. Special thanks to Diane Johnson and Charles Knaack for the whole rock analyses. This research was supported by grants to SBM from the University of Michigan, and NSF grants EAR9005414 and EAR-9315762 to AVM at the University of Houston.

\section{References}

Anderson P (1989) Proterozoic plate tectonic evolution of Arizona. In: Jenney JP, Reynolds SJ (eds) Geologic evolution of Arizona. Ariz Geol Soc Dig 17: 17-55

Bradshaw TK, Hawkesworth CJ, Gallagher K (1993) Basaltic volcanism in the Southern Basin and Range: no role for a mantle plume. Earth Planet Sci Lett 116: 45-62

Christensen NI, Fountain DM (1975) Constitution of the lower continental crust based on experimental studies of seismic velocities in granulite Geol Soc Am Bull 86: 227-236

Chung DH (1971) Elasticity and equations of state of olivines in the $\mathrm{Mg}_{2} \mathrm{SiO}_{4}-\mathrm{Fe}_{2} \mathrm{SiO}_{4}$ system. Geophys J R Astron Soc 25: 511-538

DePaolo DJ (1981) Trace element and isotopic effects of combined wallrock assimilation and fractional crystallizaton. Earth Planet Sci Lett 52: 177-184

Drake MJ, Weill DF (1975) Partition of Sr, Ba, Ca, Y, Eu ${ }^{2+}$, $\mathrm{Eu}^{3+}$, and other REE between plagioclase feldspar and magmatic liquid: an experimental study. Geochim Cosmochim Acta 39: 689-712

Esperança S, Carlson RW, Shirey SB (1988) Lower crustal evolution under central Arizona: $\mathrm{Sr}, \mathrm{Nd}$ and $\mathrm{Pb}$ isotopic and geochemical evidence from the mafic xenoliths of Camp Creek. Earth Planet Sci Lett 90: 26-40

Evensen NM, Hamilton PJ, O'Nions RK (1978) Rare-earth abundances in chondritic meteorites. Geochim Cosmochim Acta 42: 1199-1212

Farmer GL, Perry FV, Semken S, Crowe B, Curtis D, DePaolo DJ (1989) Isotopic evidence on the structure and origin of subcontinental lithospheric mantle in southern Nevada. J Geophys Res 94: 7885-7898

Frey FA, Prinz M (1978) Ultramafic inclusions from San Carlos, Arizona: petrologic and geochemical data bearing on their petrogenesis. Earth Planet Sci Lett 38: 129-176

Green TH (1994) Experimental studies of trace-element partitioning applicable to igneous petrogenesis - Sedona 16 years later. Chem Geol 117: 1-36
Hart SR (1984) A large-scale isotope anomaly in the Southern Hemisphere mantle. Nature 309: 753-757

Humphreys ED, Dueker KG (1994a) Western U.S. upper mantle structure. J Geophys Res 99: 9615-9634

Humphreys ED, Dueker KG (1994b) Physical state of the western U.S. upper mantle. J Geophys Res 99: 9635-9650

Johnson CM, Thompson RA (1991) Isotopic composition of Oligocene mafic volcanic rocks in the northern Rio Grande Rift: evidence for contributions of ancient intraplate and subduction magmatism to evolution of the lithosphere. J Geophys Res 96: 13593-13608

Kempton PD, Harmon RS, Hawkesworth CJ, Moorbath S (1990) Petrology and geochemistry of lower crustal granulites from the Geronimo Volcanic Field, southeastern Arizona. Geochim Cosmochim Acta 54: 3401-3426

Kempton PD, Fitton JG, Hawkesworth CJ, Ormerod DS (1991) Isotopic and trace element constraints on the composition and evolution of the lithosphere beneath the southeastern United States. J Geophys Res 96: 13713-13735

Kumazawa M (1969) The elastic constants of single crystal orthopyroxene. J Geophys Res 74: 5973-5980

Langmuir CH, Vocke RD Jr, Hanson GN, Hart SR (1978) A general mixing equation with applications to Icelandic basalts. Earth Planet Sci Lett 37: 380-392

McDonough WF (1990) Constraints on the composition of the continental lithospheric mantle. Earth Planet Sci Lett 101: 1-18

McGuire AV (1994) Southern Basin and Range province crustmantle boundary: evidence from gabbroic xenoliths, Wikieup, Arizona. J Geophys Res 99: 24263-24273

Menzies M, Kempton P, Dungan M (1985) Interaction of continental lithosphere and asthenospheric melts below the Geronimo Volcanic Field, Arizona, U.S.A. J Petrol 26: 663-693

Mukasa SB, McCabe R, Gill JB (1987) Pb-isotopic compositions of volcanic rocks in the West and East Philippine island arcs: presence of the Dupal isotopic anomaly. Earth Planet Sci Lett 84: $153-164$

Navon O, Stolper E (1987) Geochemical consequences of melt percolation: the upper mantle as a chromatographic column. J Geol 95: 285-307

Norman MD, Leeman WP, Blanchard DP, Fitton JG, James D (1989) Comparison of major and trace element analyses by ICP, XRF, INAA, and ID methods. Geostandards Newsletter 13: 283-290

Perry FV, Baldridge WS, DePaolo DJ (1987) Role of asthenosphere and lithosphere in the genesis of late Cenozoic basaltic rocks from the Rio Grande Rift and adjacent regions of the southwestern United States. J Geophys Res 92: 9193-9213

Reid M, Hart SR, Padovani E (1982) Evolution of the lower crust beneath Kilbourne Hole, NM. Geol Soc Am Abstr Prog 14: 597

Reisberg L, Zindler A (1986) Extreme isotopic variations in the upper mantle; evidence from Ronda. Earth Planet Sci Lett 81: 29-45

Roden MF, Shimizu N (1993) Ion microprobe analyses bearing on the composition of the upper mantle beneath the Basin and Range and Colorado Plateau provinces. J Geophys Res 98: 14091-14108

Roden MF, Irving AJ, Murthy VR (1988) Isotopic and trace element composition of the upper mantle beneath a young continental rift: results from Kilbourne Hole, New Mexico. Geochem Cosmochim Acta 52: 461-473

Sass JH, Lachenbruch AH, Galanis SP Jr, Morgan P, Priest SS, Moses TH Jr, Munroe RJ (1994) Thermal regime of the southern Basin and Range province: 1. Heat flow data from Arizona and the Mojave Desert of California and Nevada. J Geophys Res 99: 22093-22119

Smith D, Arculus RJ, Manchester JE, Tyner GN (1994) Garnetpyroxene-amphibole xenoliths from Chino Valley, Arizona, and implications for continental lithosphere below the Moho. J Geophys Res 99: 683-696

Takazawa E, Frey FA, Shimizu N, Obata M, Bodinier JL (1992) Geochemical evidence for melt migration and reaction in the upper mantle. Nature 359: 55-58 
Wells PRA (1977) Pyroxene thermometry in simple and complex systems. Contrib Mineral Petrol 62: 129-139

Wilshire HG (1990) Lithology and evolution of the crust-mantle boundary region in the southwestern Basin and Range province. J Geophys Res 95: 649-665

Wilshire HG, Meyer CE, Nakata JK, Calk LC, Shervais JW, Nielson JE, Schwarzman EC (1988) Mafic and ultramafic xenoliths from volcanic rocks of the western United States. US Geol Surv Prof Pap 1443

Wilshire HG, McGuire AV, Noller JS, Turrin BD (1991) Petrology of lower crustal and upper mantle xenoliths from the Cima Volcanic Field, California. J Petrol 32: 169-200

Zindler A, Hart SR (1986) Chemical geodynamics. Ann Rev Earth Planet Sci 14: 493-571 